\title{
Surfactant degradative plasmids
}

\author{
L. A. Taranova, S. N. Dybkova, V. G. Grishchenkov', \\ E. A. Mordukhova ${ }^{1}$, A. M. Boronin ${ }^{1}$ \\ Institute of Biocolloidal Chemistry, National Academy of Sciences of Ukraine \\ 42, Vernadskoho str., Kyiv, 03142, Ukraine
}

It has been shown that the degradation of anionic, cationic and ampholytic surfactants by pseudomonads can be controlled by the plasmids with size of $60-130 \mathrm{~kb}$. Most plasmid strains that degrade surfactants are capable of conjugative transfer and elimination from bacteria cells. Restriction patterns of plasmids do not reveal significant homology between plasmids.

Introduction. The data about microorganisms able to utilize cationic and anionic surfactants for metabolism are insufficient. The genetic control of their degradation has not been clearly determined yet.

The plasmid localization of the genes responsible for degradation of an anionic surfactant, alkyl benzenesulfonate (ABS), was first shown by Caine et al. [1]. They discovered a conjugative plasmid controlling at least one step of ABS degradation - the cleavage of sulfonic group in the strain-degrader Pseudomonas testosteroni. Though the biochemical aspects of this problem had been investigated [2], further studies on the genetic control and regulation of the ABS degradation were not made.

This is the only report of a possible plasmid control in the case of ABS and of chromosomal localization of degradative genes for naphthalene sulfonates [3].

Studies on the localization of genetic determinants controlling surfactant degradation expand our knowledge about microorganism-degraders. The data obtained may be used for construction of new strainsdestructors which could be perspective for the waste water treatment. This is important for the development of biotechnologies aimed at purifying waste water from these toxicants.

We have selected and characterized highly active bacterial strains which degrade ionogenic surfactants

(C) L. A. TARANOVA, S. N. DYBKOVA, V. G. GRISHCHENKOV, E A MORDUKHOVA, A. M. BORONIN, 2000 referring to different classes [4, 5$]$. Some of them have been tested for the ability to purify waste water on the industrial scale $[6,7]$.

The localization of the genetic determinants controlling transformation of ionogenic surfactants by bacteria-degraders has been shown.

Materials and Methods. The following surfactants were used in the study:

Anionic surfactants

Volgonat, $\left[\left(\mathrm{C}_{n} \mathrm{H}_{2 n+1} \mathrm{C}_{m} \mathrm{H}_{2 m+1}\right) \mathrm{CHSO}_{3}\right]$, containing $40 \%$ of the major compound (sodium alkansulfonate), where $n+m=11-17$. The sample of volgonat contains nonsulfonated compounds, $\mathrm{NaCl}(6 \%)$, $\mathrm{Na}_{2} \mathrm{SO}_{4}(1 \%), \mathrm{Na}_{2} \mathrm{SO3}(0.006 \%), \mathrm{Fe}(0.8 \%)$, $\mathrm{NaOH}(0.1 \%)$.

Alkylsulfate, $\left[\mathrm{C}_{n} \mathrm{H}_{2 n+1} \mathrm{OSO}_{3} \mathrm{Na}\right]$, containing $30 \%$ of the major compound, where $n=16-18, \mathrm{Na}_{2} \mathrm{SO}_{4}$ (2\%).

DNS-A, $\left[\mathrm{NaO}_{3} \mathrm{SCH}(\mathrm{COONa}) \mathrm{CH}_{2} \mathrm{COOCH}_{2} \mathrm{CH}_{2}-\right.$ $\mathrm{N}(\mathrm{H}) \mathrm{OOC}_{n} \mathrm{H}_{2 n+1}$ l, containing $35 \%$ of the major compound (disodium mono-2-(alkanoamino)ethylsuccinatosulfonate, where $n=9-12$. The sample contains nonsulfonated compounds, $\mathrm{Na}_{2} \mathrm{SO}_{4}(7 \%)$ and $\mathrm{Na}_{2} \mathrm{SO}_{3}(2 \%)$

Metaupon, $\left[\mathrm{C}_{n} \mathrm{H}_{2 n+1} \mathrm{CONHC}_{2} \mathrm{H}_{4} \mathrm{SO}_{3} \mathrm{Na}\right]$, containing $50 \%$ of the major compound.

ABS (chloric sulfonol), $\left[\mathrm{C}_{n} \mathrm{H}_{2 n+1} \mathrm{C}_{6} \mathrm{H}_{4} \mathrm{SO}_{3} \mathrm{Na}\right]$, containing $40 \%$ of the major compound (alkylbenzenesulfonate) obtained on the kerosene basis, where $n=10-13$. Its fractional composition: $\mathrm{C}_{1-10}-20 \%$, $\mathrm{C}_{11-18}-80 \%$. The sample of ABS contains nonsul- 
fonated compounds $(2 \%), \mathrm{Na}_{2} \mathrm{SO}_{4}(6 \%)$ and $\mathrm{Fe}$ $(0.006 \%)$.

SDS (sodium dodecylsulphate), $\left[\mathrm{C}_{11} \mathrm{H}_{23} \mathrm{CHSO}_{3}\right.$ $\mathrm{Na}$ ], containing $99 \%$ of the major compound.

Ampholytic surfactants

Cyclimide, containing the major compound (30 \%), where $\mathrm{NaCl}(10-11 \%)$ and moisture (nearly $60 \%$ ).

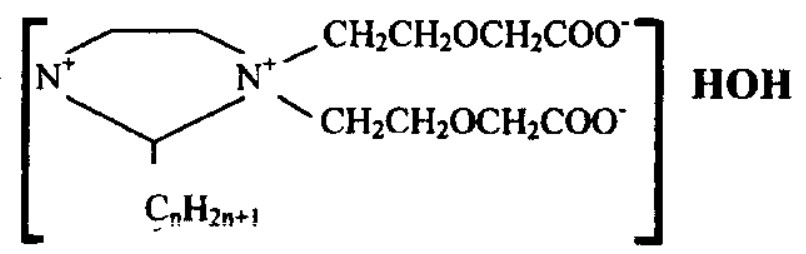

Amidobethaine (trisodium N,N,N'-triacetate-2[N-acyl-N-(2-hydroxyethyl)-amino ]ethyl ammonium hydroxide), containing the major compound (40\%), where $\mathrm{NaCl}(14.5 \%)$ and moisture $(45 \%)$.

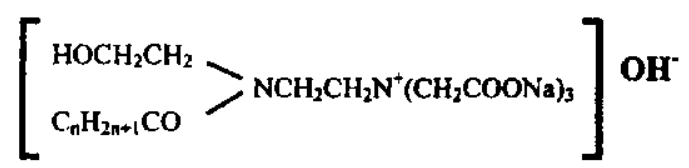

Alkyl aminobispropionate (disodium N-alkylaminobis ( $3,3^{\prime}$-propionate) (AABP), containing the major compound $(85-88 \%)$, where $n=18-20$, amines $(1 \%)$.

Cationic surfactants

Catamine AB $\left\{\left[\mathrm{C}_{n} \mathrm{H}_{2 n+1} \mathrm{~N}^{+}\left(\mathrm{CH}_{3}\right)_{2} \mathrm{CH}_{2} \mathrm{C}_{6} \mathrm{H}_{5}\right] \mathrm{Cl}^{-}\right\}$, containing the major compound $(50 \%)$, where $n=$ $=10-18$, tertiary amines $(0.6 \%)$, salts of tertiary amines $(1.8 \%$, moisture (nearly $47 \%$ ).

Alkamone DC $\left\{\left[\mathrm{C}_{n} \mathrm{H}_{2 n+1} \mathrm{OCH}_{2} \mathrm{~N}^{+}\left(\mathrm{CH}_{3}\right)\left(\mathrm{CH}_{2}-\right.\right.\right.$ $\left.\left.\mathrm{CH}_{3}\right)_{2}\right]\left[\mathrm{CH}_{3} \mathrm{SO}_{4}^{-}\right]$, containing the major compound $(90 \%)$, where $n=10-18$, secondary amines (2.7$3.5 \%$ ), moisture (nearly $6.5 \%$ ).

Ethonium, (1,2-[N, N-bis (dimethyl)-N, $\mathbf{N}^{\prime}-$ bis (decylacetate) ethylene diammonium dichloride).

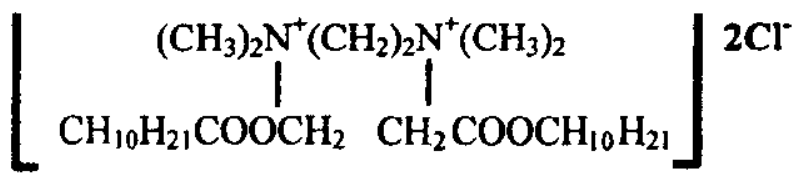

The bacterial strains-degraders of surfactants are given in Table. Bacteria were grown in LB broth and agar. The medium of the following composition $\left(\mathrm{g} \cdot \mathrm{I}^{-1}\right)$ was used as minimal: $\mathrm{K}_{2} \mathrm{HPO}_{4}-1.0 ; \mathrm{NH}_{4} \mathrm{NO}_{3}-1.0$; $\mathrm{KCl}-0.5 ; \mathrm{MgCl}_{2}-0.1$. $15 \mathrm{~g}$ of agar was added to obtain agarized medium. Anionic and cationic surfactants $\left(0.3 \mathrm{~g} \cdot \mathrm{I}^{-1}\right)$ were employed as the sole carbon and energy source.

Strain Escherichia coli K802 [14] were grown at $37^{\circ} \mathrm{C}$, other strains at $28^{\circ} \mathrm{C}$.

In the work the following plasmids have been employed: $p B S 222$ A-15 ( $\left.\mathrm{Tc}^{r}, \mathrm{Cm}^{r}\right)$, pLAFR5 (21,5 kb) [15] , pRK2013 (Rep ColE1) [16], RP4 $(55 \mathrm{~kb})$ [17], NPL-1 (98 kb), pBS2 (130 kb).

To eliminate plasmids, the cells were treated with mitomycin $\mathrm{C}$, using the method of Rheinwald et al. [8].

For matings, the donor and recipient cells (at the approximate density of $10^{8}$ cell mll $\mathrm{m}^{-1}$ ) were mixed on LB plates in a ratio of 1:2. The plates were incubated for $2-4 \mathrm{~h}$ ( in some cases up to $18 \mathrm{~h}$ ) at $28^{\circ} \mathrm{C}$. The cells were scrapped off the plates and suspended in $0.56 \% \mathrm{NaCl}$ solution and transferred onto selective medium. The transconjugants obtained were passaged thrice on the respective media.

Bacterial strains used in this study

\begin{tabular}{|c|c|c|}
\hline Strain (plasmid) & $\begin{array}{l}\text { Relevant charac- } \\
\text { teristics }\end{array}$ & Reference of Source \\
\hline P. alcaligenes TR & w. t., & $\begin{array}{l}\text { Culture Collection, } \\
\text { ICWC of the } \\
\text { Ukrainian Acad. Sci. }\end{array}$ \\
\hline P. testosteroni To & w. t., $\mathrm{Abs}^{+}$ & Ibid \\
\hline P. fluorescence TR & w. t., $\mathrm{Kat}^{+}$ & * \\
\hline P. mendocina TO & w. t., Alk ${ }^{+}$ & * \\
\hline P. stutzeri AT & w. t., Etn $^{+}$ & * \\
\hline P. putida TO & w. t., $\mathrm{Abt}^{+}$ & * \\
\hline P. desmolytica $\mathrm{C37}$ & w. t., $\mathrm{Clm}^{+}$ & * \\
\hline P. rathonis $\mathrm{T}$ & w. t., $\mathrm{Vol}^{+}$ & * \\
\hline Achromobacter eurydice TK & w. t., Dns ${ }^{+}$ & * \\
\hline P. putida K & w. t., Met ${ }^{+}$ & * \\
\hline Pseudomonas sp. 2T/1 & w. t., Sds ${ }^{+}$ & * \\
\hline P. aeruginosa $1 \mathrm{C}$ & w. t., Last & * \\
\hline
\end{tabular}

N o t e: w. t. - wild type or prototroph; utilization: Abs - alkyl benzenesulfonate; Kat - katamine; Alk - alkamone; Etn - etonium; Abt - amidobethaine; Clm - cyclimide; Abp - alkyl aminobispropionate; Vol - volgonat; Dns - disodium mono-2 (alkanoamino) ethylsuccinatosulfonate; Las - alkylsulfate; Met - metaupon. 
Several modifications of the alkaline lysis method were used to isolate plasmid DNA [9-13]. The size of plasmid DNA was estimated by comparing its electrophoretic mobility with standard plasmid DNAs. pLAFR5 $(21.5 \mathrm{~kb}), R P 4(55 \mathrm{~kb}), N P L-1(98 \mathrm{~kb})$ and $p B S 2(130 \mathrm{~kb})$ which were used as marker plasmids.

The digestion of plasmid DNA was performed by EcoRI («Promega», USA) according to the supplier's protocol.

Results and Discussion. As the biodegradation of different synthetic compounds are frequently controlled on the genetic level by degradative plasmids (D-plasmids) $[14,15]$, the selected strains (Table) were tested for the presence of plasmid DNA. The most strains of bacteria-destructors have been selected under the continuous-flow conditions. Continuous cultivation was carried out in bioreactor of column type with a ceramic carrier under forced aeration. The immobilization of bacteria on a ceramic carrier was made by adhesion $[4,5]$.

A comparative study of the electrophoretic mobility of tested and marker plasmids of known sizes allowed us to establish the following: strains-degraders of anionic surfactants: $P$, rathonis $\mathrm{T}\left(\mathrm{Vol}^{+}\right), P$. aeruginosa 1C (Las $\left.{ }^{+}\right)$, Pseudomonas sp. 2T/1 $\left(\mathrm{Sds}^{+}\right)$, $P$. putida $\mathrm{K}\left(\mathrm{Met}^{+}\right)$have one plasmid of about $100 \mathrm{~kb}$; strain $P$. alcaligenes TR $\left(\mathrm{ABS}^{+}\right.$) have one plasmid of about $130 \mathrm{~kb}$; strain Achromobacter eurydice TK (Dns ${ }^{+}$) have one plasmid with less size (Fig. 1); strains $P$. fluorescens TR $\left(\right.$ Alk $\left.^{+}\right), P$. mendocina TO

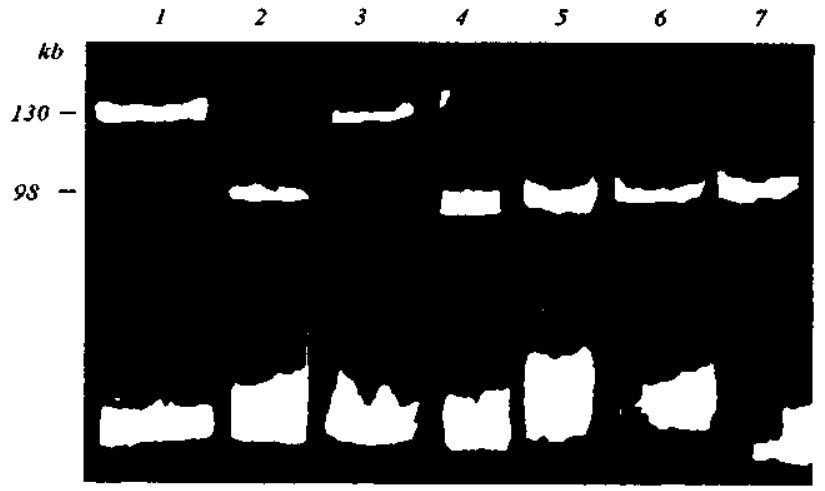

Fig. 1. Electrophoretic mobility of plasmids DNA of bacteriadegraders of anionic surfactants: $I$ - Pseudomonas putida 231 (pBS2) (130 kb); $2-P$. putida $202(N P L-I)(98 \mathrm{~kb}) ; 3-P$ alcaligenes TR; $4-P$. rathonis $\mathbf{T} ; 5-P$. putida $\mathbf{K} ; 6-$ Achromobacter eurydice TK; $7-P$. aeruginosa $1 \mathrm{C}$

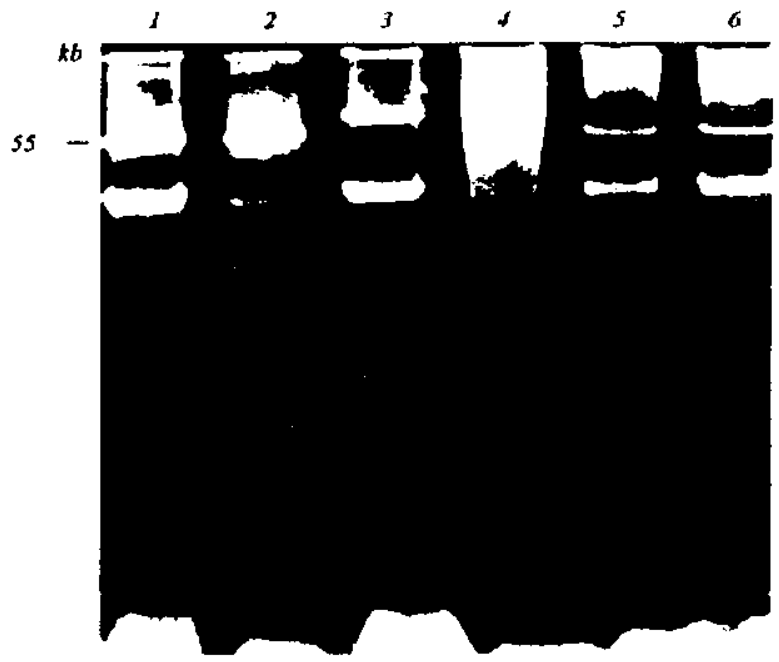

Fig. 2. Electrophoretic mobility of plasmids DNA from rains of bacteria-degraders of cationic and ampholytic surfactants: $I$ plasmid $R P 4$ (55 kb); $2-P$. fluorescence TR; $3-P$. mendocina TO; 4, 5-P. putida TO; $6-P$. stutzeri AT

$\left(E n^{+}\right)$harboured one plasmid each of about $60-70$ kb. The electrophoretic mobility of the plasmids detected in strains $P$. putida TO $\left(\mathrm{Abp}^{+}\right), P$. stutzeri AT $\left(\mathrm{Abt}^{+}\right)$was close to the marker plasmid RP4 of 55 kb (Fig. 2).

We have failed to detect plasmid DNA in straindestructor of cyclimide, $P$. desmolytica C37, $P$. testosteroni $\mathrm{TO}$, by screening techniques for realization of plasmid DNA such as alkaline lysis method with several modifications $[10-13]$.

Fig. 3 demonstrates the fragments of plasmid DNA isolated from degrader strains digested by EcoRI. It has been shown that the different plasmids of bacteria-degraders have different restriction patterns.

Curing of plasmids may be induced by chemical reagents, i. e. acridine orange NO, ethidium bromide, SDS, mitomycin C (MC). For curing plasmid DNA was used $\mathrm{MC}$ in concentration $1,25-30.0 \mu \mathrm{g} \cdot \mathrm{ml}^{-1}$. The sublethal MC concentrations were $20 \mu \mathrm{g} \cdot \mathrm{ml}^{-1}$ for anionic degrader - strain $P$. alcaligenes $\mathrm{TR}$ and strains degraders of ampholytic and cationic surfactants 30.0 and $20.0 \mu \mathrm{g} \cdot \mathrm{ml}^{-1}$, respectively. The clones which lost the ability for utilization of surfactants $\left(\mathrm{Sac}^{+}\right.$phenotype) were obtained for strains $P$. rathonis $\mathrm{T}, P$. alcaligenes $\mathrm{TR}, P$. putida $\mathrm{TO}, P$. stutzeri AT, $P$. fluorescens TR , $P$. putida $\mathrm{K}$ and $P$. 


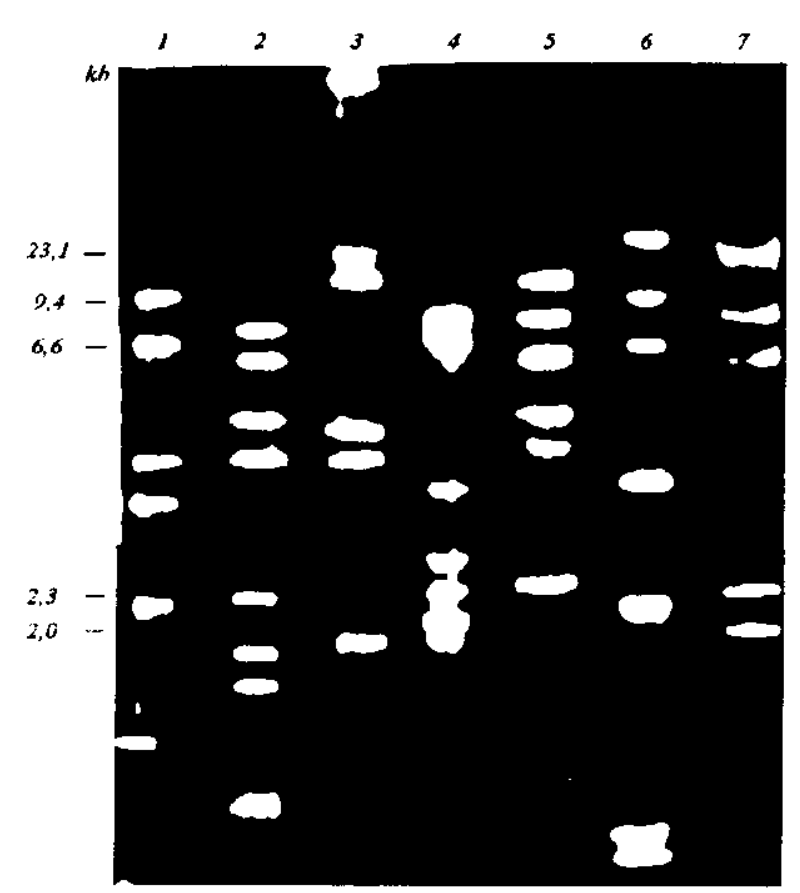

Fig. 3. Electrophoretic mobility of restrictions patterns DNA plasmids of strains-degraders of surfactants: $I-P$. mendocina TO; $2-$ Achromobacter eurydice TK; $3-P$. putida TO; $4-P$. alcaligenes $\mathrm{TR} ; 5-P$. fluorescence $\mathrm{TR} ; 6-P$. rathonis $\mathrm{T} ; 7-$ marker DNA phage $\lambda /$ HindIII

mendocina TO. The occurrence frequency of such variants was $0.4-1.8 \%$. We failed to observe the reversions to $\mathrm{Sac}^{+}$phenotype in most cured mutants. Plasmid DNA was not found in clones with lost ability for utilization of surfactants, except for the strain $P$. fluorescens TR.

The results obtained indicate the plasmid localization of the surfactant degradation determinants. To study whether the plasmids of strains degrading surfactants are able to conjugative transfer the experiments on mating have been carried out.

The transconjugants obtained were selected on the media supplemented with an appropriate surfactant as a sole carbon source. The plasmid DNA of expected molecular mass has appeared in transconjugant cells. The frequency of appearing $\mathrm{Sac}^{+}$ phenotype was $10^{-6}$ to $10^{-3}$.

The high frequency of the $\mathrm{Alk}^{+}$phenotype losing induced by mitomycin $\mathrm{C}$ favours the above suggestion. To elucidate the ability of the plasmid from strain $P$. fluorescens TR for conjugative and mobilization trans- fer, we tested its ability to mobilize the non-conjugative plasmid $p B S 222 \mathrm{~A}-15$. This plasmid was transferred to strain $P$. fluorescens TR by using a helper plasmid $p R K 2013$ followed by a series of matings in which the above strain was employed as a donor of plasmid $p B S 222 \mathrm{~A}-15$, while strains of $E$. coli and $P$. putida were employed as recipients. If own plasmid of strain $P$. fluorescens was conjugative, the mobilization transfer of a small plasmid $p B S 222$ A-15 to recipient cells would be observed. Yet, numerous experiments failed to reveal this plasmid conjugative transfer at a frequency less than $10^{-9}$. So, the question related to the resident plasmid ability for conjugation still remains open. As for this plasmid functional significance, one may probably consider it to be the D-plasmid harbouring genes that control alkamone utilization.

Thus, we have shown that the degradation of anionic, cationic and ampholytic surfactants by pseudomonas is probably controlled by plasmid genes. Most plasmids found in strains-degraders of surfactants proved to be conjugative and may be used by bacteria for the degradation of ecologically hazardous compounds in the purification systems.

Acknowledgements. This work was supported by SCJW European Research Fellowships. We are very grateful to S. C. Johnson Corp. for financial help.

Л. А. Таранова, С. М. Дибкова, В. Г. Гриченков, о. А. Мордухова, В. Г. Боронін

Плазміди біодетрадації поверхнево-активних речовин

Резюме

Показано, що деградація багатьох аніонних, катіонних та амфолітних поверхнево-активних речовин (ПАР) у псевдомонад контролюються плазмідами розміром 60-130 тис. $n$. Більиість плазмід здатні до кон югативного переносу та елімінаціі з бактеріальних клітин. Створені первинні рестрикційні карти плазмід біодеградацї̈ ПАР мають значну різницю.

Л. А. Таранова, С. Н. Дьбкова, В. Г. Грищенков,

E. А. Мордухова, В. Г. Боронин

Плазмиды биодеградации поверхностно-активных веществ

Резюме

Показано, ито деградация многих анионных, катионных и амфолитных поверхностно-активных вещесте у псевдомонад контролируется плазмидами размером 60-130 тыс. n. Большинство плазмид способны к конбюгативному переносу и элиминации из бактериальных клеток. Полученные первичные рестрикционные карты данных плазмид имеют значительные различия.

\section{REFERENCES}

1. Jonston J. B., Murray K, Cain R. B. Microbial metabolism of aryl sulfonates. A reassesment of colorimetric methods for the determination of sulfite and their use in measuring desulfona- 
tion of aryl and alkylbensene sulfonates // Ant. van Leeuw. J. Microbiol.-1975.-41, N 4.-P. 493-511.

2. Kerstesz M. A., Cook A. M., Lesinger T. Microbial metabolism of sulfur- and phosphorus- containing xenobiotics // FEMS Microbiol. Rev. -1994.-15, N 2-3.-P. 195-215.

3. Brilon C., Beckmann W., Hellwig M., Knackmuss H. J. Enrichment and isolation of naphthalenesulfonic acid-utilizing Pseudomonads // Appl. Environ. Microb.-1981.-42, N 1.P. 39-43.

4. Stavskaya S. S., Udod V. M., Taranova L. A., Krivets I. A. Microbiological purification of water from surfactants.-Kyiv: Naukova Dumka, 1988. -182 p.

5. Taranova $L$ A., Ovcharov $L F$., Rotmistrov $M$. N. Bacterial degaradation of ampholytic surfactants // Biotekhnologiya.1990. -N 4.-P. $31-34$.

6. Stavskaya S. S., Taranova L A., Krivets I. A., Grigorieva $T$. Tu, Rotmistrov $M$. N. Microbiological method of waste water treatment from anionic surfactants // Khimiya I Tekhnologiya Vody. - 1982.-4, N 4.-P. 368-370.

7. Taranova I. A., Grishchenko S. V., Radchenko O. S., Trachevsky V. V., Delemenchuk N. V. Microbiological treatment of waste water from cationic surfactants // Khimiya $i$ Tekhnologiya Vody.-1991.-13, N 11.-P. 1051-1056.

8. Rheinwald J. G., Chakrabarty A. M., Gunsalus I. C. A transmissible plasmid controlling camphor oxidation in Pseudomonas putida // Proc. Nat. Acad. Sci. USA.-1973.-70, N 3.-P. 885-889.

9. Miller J. H. Experiments in Molecular Genetics.-Moscow: Mir, $1976 .-320 \mathrm{p}$
10. Babykin M. M., Zinchenko V. V., Bibikova M. V., Shestakov $S$. V. Isolation of large plasmids // Mol. Genetika, Microbiologiya : Virusologiya.-1984.-N 7.-P. 21-23.

11. Gerhardt P., Murray R. G. E., Costilow R. N., Nester E. W., Wood W. A., Krieg N. R., Phillips G. B. Manual of Methods for General Bactertology.-Washington D. C.: ASM press, 1981.-P. 137.

12. Wheatcroft R., Williams $P$. A. Rapid method for the study of both stable and unstable plasmids in Pseudomonas // J. Gen. Microbiol.-1981.-124, N 2.-P. 433-437.

13. Eckhardt $T$. A rapid method for the identification of plasmid desoxyribonucleic acid in bacteria // Plasmid.-1978.-1, N 4.-P. 584-588.

14. Maniatis T., Fritch E. F, Sambrook J. Molecular cloning: A laboratory manual.-New York, 1989.-P. 1435.

15. Keen N. T., Tamaki N., Kobayashi D., Trollinger D. Improved broad-host-range plasmids for DNA cloning in gram-negative bacteria // Gene.-1988. -70, N 1.-P. 191-197.

16. Figurski D. H., Helinski D. R. Replication of an origin containing derivative of plasmid $R K 2$ dependent on a plasmid function provided in trans // Proc. Nat. Acad. Sci. USA.1979. - 76, N 4.-P. 1648-1652.

17. Datta N., Hedges R. W., Shaw E. J., Sykes R. B., Richmond $M$. $H$. Properties of an $\mathrm{R}$ factor from Pseudomonas aeruginosa // J. Bacteriol. -1971.-108, N 3.-P. 1244-1249.

УдК 579.25 .017 .7 Received 07.02.2000 